\title{
The Effect of Social Media on Consumer Purchase Behaviour in the Mobile Telephony Industry in Zimbabwe
}

\author{
Forbes Makudza ${ }^{1 *}$, Cleopatra Mugarisanwa ${ }^{2}$, Shingirai Siziba ${ }^{1}$
}

\begin{abstract}
${ }^{1}$ Manicaland State University of Applied Sciences, ZIMBABWE
${ }^{2}$ Bindura University of Science Education, ZIMBABWE

*Corresponding Author: forbesmakudza@gmail.com
\end{abstract}

Citation: Makudza, F., Mugarisanwa, C. and Siziba, S. (2020). The Effect of Social Media on Consumer Purchase Behaviour in the Mobile Telephony Industry in Zimbabwe. Dutch Journal of Finance and Management, 4(2), em0065. https://doi.org/10.29333/djfm/9299

ARTICLE INFO

Received: 31 Jul. 2020

Accepted: 25 Sep. 2020

\begin{abstract}
This paper examines the causal relationship between social media and consumer purchasing behaviour in the mobile telephony industry in Zimbabwe. The study was driven by a strong desire to convert social media usage into desirable purchase behaviour. Social media was examined using four variables namely, firm generated communication, user created communication, word of mouth and social media platform. The study results indicate that social media is a significant driver of consumer purchase intention. Consumer purchase behaviour is mainly driven by social media word of mouth, whilst firm generated content was found to be inversely related to purchase intention. User generated social media communication resulted in a moderately weak association with purchase behaviour, whilst an insignificant association was obtained between social media platform and consumer purchase intention. The results imply that social media is an effective tool but needs to be adapted so as to minimize generating content which distorts desirable consumer behaviour. The researchers therefore recommend a cautious social media campaign which generates more desirable viral content.
\end{abstract}

Keywords: social media, consumer behaviour, purchase intention, marketing, word of mouth

\section{INTRODUCTION}

The past decade has seen rapid improvements in internet technological developments the world over. The fast-paced adoption of Internet usage enabled marketers to reap and augment the usage of Internet technologies through electronic commerce (Ghannam, Al-Natour, and Alzeidat, 2018) However, electronic commerce promoted product and service ubiquity yet it presented a one-way communication which hindered effective consumer feedback. That limitation was fast addressed with the dawn of social media through Web 2.0 which enabled the usage of a range of interactive tools and communication techniques which are user generated.

Zimbabwe has been a haven of social media marketing in the mobile telephony industry. Techzim (2019) indicates that there were over 1.2 million users of social media in Zimbabwe by the culmination of 2020 . The industry is primarily made up of three companies; Econet, Netone and Telecel. The rate at which these companies compete for market share and consumer attention has been so aggressive so much that the marketing space is now a red ocean. Social media was thus seen as a prudent way to further broaden the competitive space and to attract consumer behavioural intention..
However, regardless of all the efforts done by players in the mobile telephony industry in Zimbabwe to promote value through social media, the extent to which social media is affecting consumer behaviour has never been measured using a systematic research. The effect of social media marketing becomes more emergent given the rampant negative social media posts that are posted almost on a daily basis. The rate at which users generate their posts on social media sites is also a cause for concern. Ndurura (2020) posits that on average, telecommunication users post in excess of 10000 social media messages daily. These messages have a great impact of influencing other consumers either positively and negatively. Amongst the unresolved issues in social media marketing in the mobile telephony industry in Zimbabwe, is the problem of how to turn "likes" into purchases.

This study therefore seeks to examine how social media can be used effectively in the mobile telephony industry so as to enhance desirable purchase behaviours. 


\section{LITERATURE REVIEW}

\section{The Concept of Social Media}

Meslat (2018) defines social media (SM) as websites or applications, which allow users to participate in social networking by creating or sharing content. Similarly, Zhou and Zimmermann (2013) reiterate that social media involves the use of internet-based media that allows people to participate in the marketing, selling, comparing, rating, buying and sharing of products and services in both offline and online market places and in communities. Alnsour, Ghannam, AlNatour and Alzeidat (2018) further make a clarification on the platforms that social media uses. Social media includes networking site such as Facebook, Twitter, Instagram and YouTube, among others. However, it also includes blogging sites, emails, chat rooms and forums (Alnsour et al., 2018).

Social media are dynamic tools that facilitate online relationships between the firm and the users (Ramsunder, 2011). With social media, firms can now facilitate a strong dyadic relationship with their consumers through a constant two-way communication. According to Ndurura (2020), social media enhances relationship creation and maintenance through natural and general conversations between people about a topic of mutual interest. To that end, Yin et al. (2019) indicate that social media is about sharing information and sometimes involves decision making.

Social media involves several social online channels (or networking sites) and are subject to change over time (Ramsunder, 2011). It is participative and the audience (consumers) are part of the creative process which generates real time content or real time conversations. Commenting on a related issue, Diebes and Iriqat (2019) concluded that social media empowers consumers to be active buyers not passive information receivers. This makes social media users influencers of other consumers in both online and offline selling platforms.

According to Putter (2017), in 2017 nearly one in four of people worldwide were using social media network sites - a number close to 1.5 billion people. Three years later, GlobeStat (2020) indicate that that number of social media users had significantly outnumbered two billion users. This indicates that social media usage was on the rise over the few past years. In addition to that, Alnsour et al. (2018) indicate that social media usage was projected to further grow by $7 \%$ annually.

The majority of social media users were young adults and children, with the elderly being among the least users (Putter, 2017). However, Lilima (2020) found an interesting piece of evidence about age and social media usage. Lilima (2020) found out that though consumers between 20 years and 30 years were more subscribed to social media, the rate of new users was high among the mature members of the society (aged between 40 and 50 years). The association between age and social media usage was also analysed by Ricardialiono (2020) and he concludes that there are significant differences among age categories and each age category has a varied propensity to use social media.

Another fascinating aspect of social media usage is how people of all gender groups relate to the usage of social media.
Literature on that regard is barraged with contradictory findings. Maoyan et al. (2014) found out that there was no statistically significant evidence that gender affects social media usage. The same notion was shared by Schivinski and Dabrowski (2018) who found out that both male and female usage of social media was the same. However, Eqwubo (2020) in his Ghanaian study found out that women were more active on social media than males. The same notion was also agreed upon in Africa by Nikita (2017).

\section{Consumer Purchase Intention}

Consumer purchase intention refers to individual's willingness to purchase a certain product or service (Yoong and Lian, 2019). Purchase intention is an effective tool in predicting buying process. Consumer's purchase intention shows the likely effect that a certain behaviour is going to be performed (Lilima, 2020). Purchase intention is also defined by Alnsour et al. (2018) as the consumer's probability of purchasing a product or a service in the future and it is directly related to consumer attitude and preference. Alnsour et al. (2018)'s reasoning therefore means that consumer purchase intention is very likely that someone will purchase the product, and there is a willingness to buy the product the next time there is a need for that product.

According to the Theory of Reasoned Action (TRA) by Fishbein and Ajzen (1975) and the Theory of Planned Behaviour (TPB) by Ajzen (1985) an individual's behaviour is predicted by his or her intention to perform the behaviour. Venkatesh et al. (2003) seconds that notion that behavioural intention predicts actual usage behaviour. A comprehensive review of 450 articles that measured the association between behavioural intention and usage behaviour by Ogut (2016) also revealed that there is a direct linear association between the two variables.

Some scholars used purchase intention as an independent variable (Campbell et al., 2011; Eqwubo, 2020). The reason behind that is the ability of purchase intention to predict actual behaviours by customers (Eqwubo, 2020). Purchase intention can thus either be positive or negative, depending on the strength of its antecedents. According to Al-qasa, Isa, and Othman (2013) positive purchase intention results into bonding with the service provider, a willingness to purchase from the service provider and increased market share. On the opposite side, unfavourable purchase intention leads consumers to show high probability of brand switching, unwillingness to purchase from the service providers and engage in negative word of mouth (Zeithalm, 1996). It was therefore noted by Parasuraman et al. (1996) that the performance of an organisation largely depends on its ability to develop positive and favourable purchase intentions in customers.

\section{Social Media and Consumer Purchase Intention}

Social media has provided a new plethora of business and marketing initiatives which influence consumers' purchase intention. According to Permatasari and Kuswadi (2018), social media has changed the dynamics of consumer behaviour by shortening the consumer buying process. The consumer buying process is a sequential process which sees consumers moving along various stages of buying. These stages are need 
recognition, information search, evaluation of alternatives and purchase. Permatasari and Kuswadi (2018), thus indicate that through social media marketing, consumer's sequential process has been reduced as consumers can skip other stages and develop an intention to buy which is more likely to lead to purchase behaviour.

Through social media, information which consumers are exposed to is now richer. This improves the second stage of the consumer buying process, information search. Social media is a rich highway where information which relates to the product can be obtained in plain text, hyper mark-up text or in downloadable magazines and pamphlets (Bruno and Dariusz, 2013).

Social media allows for ubiquitous information access. There are no geographical boundaries to marketing of goods and services on social media. Actually, Kulimula (2020) indicates that through social media a large group of audience from an array of background can gain access to the company's marketing communication. This enhances consumer purchase intention through reduced effort to get product information (Never, 2019). In addition to that, Never (2019) further posits that when information is readily available, it reduces all forms of search cost on the consumers' part and this predicts high levels of purchase intention behaviour.

Arguably the most fundamental unique element of social media which influences consumer purchase behaviour is the ability of social network platforms to promote dual forms of communication between the user and the firm (Lilima, 2020). Based on Web 2.0, social media allows users to send information through posts, reviews, ratings and likes. This information acts largely as feedback to the organisation, however it has more impact on other consumers on the social platform. Relating to this discussion, Yoong and Lian (2019) posit that user generated content is more appealing to consumers than firm generated communication. Thus, through a dual way of communication, consumers are motivated to buy through motivations generated by other consumers on social networks. The same notion was raised by Nikita (2019) that there is a positive association between user generated content and favourable behaviour of consumers.

Consumers' purchase intention is also driven by the group influence on social networks (Yoong and Lian, 2019). This follows that social media platforms enable peer and group shopping which is synonymous with a group of friends going out shopping in offline environments. Therefore, social media drives consumer purchase intention through opinion leadership and reference group effects. Because consumers have a natural tendency of belongingness, they tend to buy what other consumers are also buying. In actual fact, Yoong and Lian (2019) found a statistically significant association between group purchase on social media and consumers' behavioural intention to buy.

\section{Conceptualising Social Media Effect}

From a cross section of some studies done on social media, it was noted that the majority of studies concentrated more on social media, without giving a clearer picture of how to understand the dynamics of social media (Ricardialiono, 2020). This is categorically made clear by the absence of universally acceptable determinants of social media. Some scholars posit

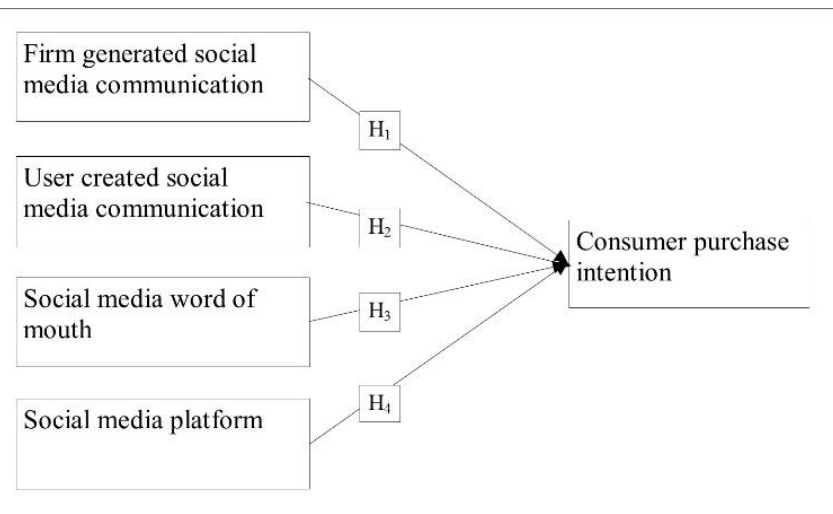

Figure 1. The conceptual framework

that social media is only two-way between the firm and the user (Poturak and Softić, 2019); whereas others posit that social media is a function of social media knowledge, commitment, training and applications (Kosarizadeh and Hamdi, 2015). That sparked an array of debate as some researchers consider social media as anything that comes from a social channel (Likula, 2020). The controversy is further promulgated as scholars like Gizlan and Mertucalis (2020) indicate that social media understanding is never complete without the inclusion of the effectiveness of the social media platform. The reasoning of Gizlan and Mertucalis (2020) was that various social media platforms (like Facebook and Twitter) appeal more to certain type of customers than they do to others. Therefore, a clear understanding of the effect of social media needs to examine the exact type of social media which drives user intention.

The study of consumer purchasing intention boarders on the Theory of Planned Behaviour (Fishbein and Ajzen, 1975). The notion being that before consumers make an actual purchase, they first develop an intention to buy. Therefore, consumer purchase intention to buy predicts the actual purchase behaviour of consumers.

In light of the foregoing, the study aims to examine the effect of social media from a holistic point of view. Therefore, the model of social media by Poturak and Softic (2019) was adopted and adapted. Poturak and Softic (2019)'s model has two determinants of social media namely, user generated content and firm created content. However, in the proposed study two other variables (word of mouth and social media platform) were added. The inclusion of the two variables was informed by the studies of Gizlan and Mertucalis (2020). Figure 1 shows the conceptual framework.

\section{Firm Generated Social Media Communication}

Firm generated social media communication relates to the content that is uploaded and posted by the company which owns the social media page (Poturak and Softic, 2019). Similarly, Bharucha (2018) indicate that firm generated content is any information which the company posts on its social network. The universal understanding of firm generated content from the views of Bharucha (2018) and Poturak and Softic (2019) is that it emanates from within the organisation.

Firm generated social media content is usually manned by the Marketing and Public Relations Department as the 
company endeavours to influence user behaviour of social media participants. Firm created content includes product updates, new releases, advertisements, and other firm generated media (Kulimula, 2020). Since this aspect is manned by the Public Relations team, its information is mainly about the beauty of the company and its products. Rarely will a company post negatively about its own operations on social media (Poturak and Softic, 2019).

According to Poturak and Softic (2019), the relationship that exist between firm generated social media content and consumer purchase intention is discoverable. In essence, Poturak and Softic (2019) indicate that there is a direct positive association between the two variables. Generally speaking, though, Poturak and Softic (2019) concluded that firm generated social media content is considered authentic and informative because it is developed by professionally trained employees. This was found to be true by Rad et al. (2011) who found out that formal reviews which were posted by the company were predictive of consumer purchase intention and action.

However, Likula (2020) argues that firm generated content is self-reflectory and thus lacks credibility in balancing the views between actual product performance and marketing sentiments. Likula (2020)'s reasoning boarders on the notion that an organisation only posts the beautiful side of its products and services and never posts anything negative about their service. The reason for that was highlighted by Ndurura (2020) who suggest that through goodwill management, companies do not want to wash their dirty linen in public. In light of the forgoing, Kulimula (2020) concludes that the ability of firm generated communication to drive consumer purchase intention was minimal, though statistically significant.

The study therefore posits that communication which originates from the firm drives purchase intention. The following hypothesis was thus stated:

$\mathrm{H}_{1}$ : Firm generated social media communication (FGSMC) has a positive effect on consumer purchase intention.

\section{User Created Social Media Communication (UCSMC)}

User created social media communication relates to content that is uploaded to social media by consumers (Poturak and Softic, 2019). These are social media posts by individual user consumers on the social media page of an organization (Bharucha, 2018). They indicate the way consumers and social media users respond to firm generated social media content (Kulimula, 2020). User created social media exist on the social media page of the company under consideration.

User generated social media communication is typically not called for by the company but is as a result of consumer feedbacks and responses. As identified by Campbell et al. (2011) consumers contribute to the process of content creation for reasons such as self-promotion, intrinsic enjoyment, and desires to change public perceptions. The growth of online brand communities, including social networking sites, has supported the increase of user-generated social media communication (Poturak and Softic, 2019).
User created communication is believed to be the major driver of consumer purchase intention. Other consumers on the social network platform are more likely to be motivated to act in a particular way by user created than firm generated social media communication (Gizlan and Mertucalis, 2020). Relating to the relationship between these two, Kulimula (2020) notes that users' views are more rational and unbiased which make them more informative during the consumer buying process. Kulimula (2020) was taking a contrasting view between user created and firm generated social media content.

Some scholars however argue that user created communication may not be authentic and may fall short of the level of informant that consumers require. For instance, Ndurura (2020) argues that user created communication may be motivated by competitors. Competitors may act as users and post negative reviews about a company's offering and products and services. When other consumers on the same social network channel view it, it may seem consumer generated yet in actual fact it will be competitor generated communication.

Though Ndurura (2020) raised a critique to the effectiveness of user created content, he was however supportive of Kulimula (2020) and Poturak and Softic (2019)'s views that the association between user created content and consumer behaviour is strong and positive. Thus, Ndurura (2020) concludes that user generated content best predicts consumers' purchase action. Therefore, in this study we posit that user created content directly impacts on consumer purchase intention, and the following hypothesis is stated:

$\mathrm{H}_{2}$ : User created social media communication (UCSMC) has a positive effect on consumer purchase intention.

\section{Social Media Word of Mouth}

Social media word of mouth (WoM) relates to social media conversations by other social players who are independent from influence by the company (Schivinski and Dąbrowski, 2013). These communications usually spread faster from one user to the other and they could be about positive or negative aspects of the company (Putter, 2017). Thus, they are also termed viral communications as they move from user to user (Bruno and Dariusz, 2013).

Word of mouth communication is generated not on the social page of the company, but on other social networks other than the company's. This makes it effective in spreading positive news to other consumers on other social networks. Hoyer and MacInnis (2016) indicate that when word of mouth is favourable, it is called positive viral communication, yet when it is bad it is called negative viral communication. In many instances, marketers aim to achieve positive viral communications and other companies have developed bizarre marketing communications which can be easily circulated through positive viral communication (Nikita, 2019).

The word-of-mouth on social media plays a major role in influencing consumers. This follows that consumers tend to believe information heard from people they have a relationship with, due to the fact that people have similarities (share the same values and preferences) and feel as members of the same communities (Hoyer and MacInnis, 2016). To further examine that, Diebes and Iriqat (2019) describe the 
level of trust as being higher with people that the consumer knows and the word-of-mouth as the primary factor behind 20 to 50 percent of all purchasing decisions.

Web 2.0 which supports social media allows people to share contents as word of mouth and that significantly influences consumers' purchasing decision making process (Gros, 2012). As consumers in social communities tend to trust their peers because they feel like they are similar, the trust level plays a major role in the buying process as magnified and influenced on social media. Gros (2012) gives an illustrative lead on the high impact of word of mouth on consumer buying behaviour. Gros (2012) notes that the increasing frequentation of reviews and opinion websites such as Epinions and TripAdvisor illustrates the fact that consumers are seeking for their peers' opinions because they estimate them as being trustworthy.

Given that consumers tend to listen to fellow peers, Kulimula (2020) encourages companies to monitor what their consumers talk about. This is prudent given the speed at which the information travels. Therefore, if user communications are negative, a company is bound to issue corrective firm generated communication so as to develop a positive user purchase intention. Therefore, we hypothesise the association between social media word of mouth and consumer purchase intention as follows:

$\mathrm{H}_{3}$ : Social media word of mouth (SMWM) has a positive effect on consumer purchase intention.

\section{Social Media Platforms/Sites}

Not all social media platforms or sites have the same level of impact towards influencing purchase intention (Ricardialiono, 2020). Social media platforms relate to social network sites which consumers use to access social networks. There are several types of social media platforms and these include micro blogging, social sharing and social reviews. A rather broader perspective of social commerce was aired by Oleynikovaa and Zorkina (2016) who grouped social commerce into seven sectors namely; Social networking (such as Facebook), Recommendation services (such as iRecommend.com) Hotel reservations (such as Hotel.com), Hand-made association (Esty.com), Peer-to-peer commerce (eBay.com), Daily deals and Collective buying platforms.

These various types of social networks are used for different purposes by consumers leading to varied consumer intention effects for each platform (Never, 2019). Relating to the association between consumer behaviour and social media type, Ricardialiono (2020) notes that social network platforms have varied influence on consumer behaviour. In a general sense, Ricardialiono (2020) indicates that Facebook is more appealing for user generated content and the promotion of word of mouth by organisations. Facebook's impact on consumer behaviour would therefore be different from Twitter whose orientation is regarded more as firm authentic generated content. (Ricardialiono, 2020).

The most common social media platforms are Facebook, Twitter, YouTube and Instagram (Never, 2019). In terms of Marketing of goods and services using Facebook, Eqwubo (2020) indicates that marketers should combine plain texts, pictures and videos to capture people's attention on Facebook. Such postings are likely to get numerous comments, wall posts and many likes from people on Facebook. According to Oleynikovaa and Zorkina (2016), Facebook can integrate people to become friends, to communicate, share interests and to spread ideas. Twitter also allows users to be followed and to create a following. Followers are exposed to all new and related post of their prime (Eqwubo, 2020).

Twitter also allows for group following and group discussions. This is essential in influencing user behaviour through reference groups. YouTube has been used to promote products through videos and jingles. Viral skirts are developed by companies using comedians and they spread as new videos. Advertisements posted on YouTube by organisations with humour appeal are more likely to receive user attention and lead to consumer purchase intention (Eqwubo, 2020). Furthermore, Tapfumaneyi (2015) notes that YouTube users can post comments on public material and influence peers' purchase decisions. Flickr is essential for branding purposes as satisfied consumers have the ability to post of their brands and products. Flickr also enhances the beauty of the product and preserves company's advertising files. In light of the foregoing discussion on the role of social media platforms, we hypothesis the association to be as follows:

\section{$\mathrm{H}_{4}$ : Social media platform (SMP) has a positive effect on consumer purchase intention.}

\section{RESEARCH METHODOLOGY}

The research followed an explanatory research design. According to Saunders, Lewis and Thornhill (2015) this type of research design measures causality between the independent variable and the dependent variable. The explanatory element of the research design was used to explain the cause and effect association between social media and consumer purchase intention. Social media was represented by four aspects whose causality was measured on consumer purchase intention. The target population for the study was made up of all social media users of the mobile telephony industry in Zimbabwe. Using the Morgan (1993) sample size extract, at 95\% confidence interval and at $5 \%$ margin of error, the sample size for an infinitive target population was identified as 384 respondents. Respondents were selected using stratified random sampling from the three players of the Zimbabwe mobile telephony industry. Data was collected using a structured questionnaire and SPSS version 21 was used to analyse the data.

\section{Reliability of the Instrument}

A set of questions were used to measure the social media conceptual framework which had five study constructs, namely; firm generated social media communication, user created social media communication, social media word of mouth, social media platforms and purchase intention. The extent to which these questions were statistically related to the variable that they were measuring was measured using the Cronbach Alpha test statistic in SPSS, and the results are shown in Table 1.

The Cronbach Alpha test statistic (Table 1) shows that all variables had a Cronbach Coefficient of 0.72 and above. This proves that all questions under study were measuring their 
Table 1. Reliability of the social media measuring instrument

\begin{tabular}{ccc}
\hline & Cronbach's Alpha & N of Items \\
\hline Firm generated social media communication & 0.851 & 5 \\
\hline User created social media communication & 0.720 & 5 \\
\hline Social media word of mouth & 0.862 & 5 \\
\hline Social media platform & 0.836 & 5 \\
\hline Purchase Intention & 0.820 & 5 \\
\hline
\end{tabular}

Table 2. Social media model summary

\begin{tabular}{|c|c|c|c|c|c|c|c|c|c|}
\hline \multicolumn{10}{|c|}{ Model Summary } \\
\hline \multirow{2}{*}{ Model } & \multirow{2}{*}{$\mathbf{R}$} & \multirow{2}{*}{ R Square } & \multirow{2}{*}{$\begin{array}{l}\text { Adjusted R } \\
\text { Square }\end{array}$} & \multirow{2}{*}{$\begin{array}{l}\text { Std. Error of } \\
\text { the Estimate }\end{array}$} & \multicolumn{5}{|c|}{ Change Statistics } \\
\hline & & & & & R Square Change & F Change & df1 & df2 & Sig. F Change \\
\hline 1 & $.348^{\mathrm{a}}$ & .121 & .118 & .68187 & .121 & 44.935 & 1 & 327 & .000 \\
\hline 2 & $.673^{\mathrm{b}}$ & .454 & .450 & .53839 & .333 & 198.504 & 1 & 326 & .000 \\
\hline 3 & $.689^{c}$ & .475 & .470 & .52871 & .021 & 13.051 & 1 & 325 & .000 \\
\hline
\end{tabular}

a. Predictors: (Constant), SM word of mouth

b. Predictors: (Constant), SM word of mouth, Firm generated SM communication

c. Predictors: (Constant), SM word of mouth, Firm generated SM communication, User created SM communication

Table 3. Coefficients of the social media model

\begin{tabular}{|c|c|c|c|c|c|c|}
\hline \multicolumn{7}{|c|}{ Coefficients $^{\mathrm{a}}$} \\
\hline & \multirow{2}{*}{ Model } & \multicolumn{2}{|c|}{ Unstandardized Coefficients } & \multirow{2}{*}{$\begin{array}{c}\text { Standardized Coefficients } \\
\text { Beta }\end{array}$} & \multirow{2}{*}{$\mathbf{t}$} & \multirow{2}{*}{ Sig. } \\
\hline & & B & Std. Error & & & \\
\hline \multirow{4}{*}{3} & (Constant) & 3.753 & .110 & & 34.12 & .000 \\
\hline & SM word of mouth & .335 & .046 & .511 & 7.270 & .000 \\
\hline & Firm generated SM communication & -.532 & .036 & -.744 & -14.64 & .000 \\
\hline & User created SM communication & .232 & .064 & .273 & 3.613 & .000 \\
\hline
\end{tabular}

a. Dependent Variable: Purchase Intention

intended variables. Collins (2015) opined that the acceptable values of Cronbach Alpha range between 0.65 and 0.95 . Thus, the study concluded that the questionnaire variables were statistically reliable.

\section{DATA FINDINGS}

The study attracted responses from 56\% male and $44 \%$ female responses. The response rate of the study was $85.6 \%$ as 329 responses were returned and validated. The study found out that on average respondents spend 2 hours and 53 minutes on social media per day (mean hours 2.88 ) whilst the majority of respondents stated that they spend 2 hours on social media daily (mode 2). Interestingly, some respondents stated that they spend a maximum of 8 hours on social media daily whilst none of the respondents can allow a day to go by without using social media (minimum hours 1 , maximum hours 8 ). The interpretation of these results is that social media acceptance and usage in Zimbabwe is high. The study also found that most consumers (58.97\%) access social media using smartphones, whilst $26.75 \%$ use their tablets and $14.29 \%$ use their laptops and computers. These results therefore mean that smartphones are mainly used by Zimbabwean consumers, hence the need for the mobile telephony industry to tailor its social media handles to suit consumers' devices.

\section{Model Testing}

Social media was measured using four variables (firm generated social media communication, user created social media communication, social media word of mouth and social media platform). The extent to which these social media variables were statistically related to purchase intention was measured using the Stepwise Regression test statistic in SPSS and the Pearson correlation test statistic. Table 2 shows the model summary.

Table 2 presents the regression models' summary. Three models are presented with varied r-squared values. Model 3 with three independent variables (word of mouth, firm generated communication and user generated communication) was adopted for analysis because it explains purchase intention by the highest rate of $47 \%$ (adjusted $r^{2}=$ 0.47). Model 4 which included the fourth independent variable, social media platform, had an insignificant F change, thus the study accepted the model with three social media determinants. The fourth determinant was thus excluded from analysis because it failed to add strength to Model 3.

Model 3 also shows a very strong and positive correlation between social media determinants and purchase intention, with a correlation coefficient of 0.689 . This means that if the variables of the model are enhanced, purchase intention of the mobile telephony consumers would be significantly enhanced. The social media model 3 was statistically significant. The pvalue of model 3 was 0.00 , with an F coefficient of 97.877 . The $\mathrm{p}$-value was below the alpha value of $0.05(\mathrm{P}=0.000<0.05)$.

Table 3 shows the coefficients of social media variables on consumer purchase intention. The same table shows the level of significance for each social media variable.

Table 3 shows that the three variables of the social media Model 3 were statistically significant with $P$-values of 0.00 . The study further tests the association between the social media variables and consumer purchase intention using the Pearson correlation test, whose results are presented in Table 4. 
Table 4. Correlation between social media variables and purchase intention

\begin{tabular}{|c|c|c|}
\hline & ons & \\
\hline & & Purchase intention \\
\hline \multirow{3}{*}{ Firm generated SM communication } & Pearson Correlation & $-.612^{* * *}$ \\
\hline & Sig. (2-tailed) & .000 \\
\hline & $\mathrm{N}$ & 329 \\
\hline \multirow{3}{*}{ User created SM communication } & Pearson Correlation & $.239^{* * *}$ \\
\hline & Sig. (2-tailed) & .000 \\
\hline & $\mathrm{N}$ & 329 \\
\hline \multirow{3}{*}{ SM platform } & Pearson Correlation & .075 \\
\hline & Sig. (2-tailed) & .173 \\
\hline & $\mathrm{N}$ & 329 \\
\hline \multirow{3}{*}{ SM word of mouth } & Pearson Correlation & $.448^{* * * *}$ \\
\hline & Sig. (2-tailed) & .000 \\
\hline & $\mathrm{N}$ & 329 \\
\hline \multirow{3}{*}{ Purchase intention } & Pearson Correlation & 1 \\
\hline & Sig. (2-tailed) & \\
\hline & $\mathrm{N}$ & 329 \\
\hline
\end{tabular}

***. Correlation is significant at the 0.01 level (2-tailed).

Table 4 shows that all other social media variables have statistically significant associations with purchase intention, except for the social media platform which recorded an insignificant $\mathrm{P}$ - value of 0.173 .

The discussion and interpretation of the results is thus made in the following section.

\section{DISCUSSION}

The Effect of Firm Generated Social Media Communication (FGSMC) on Consumer Purchase Intention

In line with regression results in Table 3, firm generated social media communication had a negative beta value of 0.744 , with a $\mathrm{T}$-value of -14.64 and a p-value of 0.00 . This shows that firm generated social media communication significantly and inversely affects purchase intention in the mobile telephony industry by $74.4 \%$. At the same time, the correlation coefficient between firm generated social media communication and consumer purchase intention was -0.612 (Table 4). The p-value of the correlation was also statistically significant at 0.00 . This therefore means that the relationship between firm generated social media communication and consumer purchase intention is moderately strong yet inverse. The study thus rejects the null hypothesis and conclude that there is statistical evidence that firm generated social media communication has a negative impact on consumers' purchase intention $\left(\mathrm{H}_{1}\right)$.

Therefore, when mobile telephony companies post more messages on social media, the willingness of consumers to buy the products go down. In other words, the more companies post social media messages the more consumers stop buying. This relationship is so strong because in every 1 message posted by mobile telephony companies, consumers' willingness to buy is reduced by $74 \%$.

Previous empirical studies also found related results. Kulimula (2020) found out that firm generated content is selfreflectory and thus lakes credibility in balancing the views between actual product performance and marketing sentiments. Schivinski and Dabrowski (2013) found out that firm generated communication was inversely related to purchase behaviour. The same result was found by other scholars (Alnsour, 2018; Kohli, Suri, and Kapoor, 2014; Permatasari and Kuswadi, 2018).

The Effect of User Created Social Media Communication (UCSMC) on Consumer Purchase Intention

Table 3 shows that user created social media communication had a positive beta value of 0.27 , with a $\mathrm{T}$ value of 3.61 and a P-value of 0.00 . These results indicate a statistically significant, moderately weak, positive impact of user created social media communication on consumer purchase intention. Table 4 also shows that the correlation coefficient of the association between user created social media communication and purchase intention was 0.239 . This shows a positive yet weak association between the two variables. However, the association is statistically significant, as attested to by a significant $p$-value of 0.00 . We therefore reject the null hypothesis and conclude that there is statistical evidence that user created social media communication has a positive impact on consumers' purchase intention $\left(\mathrm{H}_{2}\right)$.

The statistical results can be interpreted to mean that the more subscribers participate on mobile telephony companies' social media pages, the more consumers purchase their services. However, the extent to which user created content can influence purchase intention of consumers was lesser.

Poturak and Softic (2019) confirmed that users are powerful and rational beings who believe in what other previous product users comment on. The same findings were established by Kulimula (2020) who found out a strong positive association between user created social media communication and consumer purchase intention. The study concluded that companies should never underrate what other users posts. Regarding the destructive power of user content, Ndurura (2020) found out that through user to user and viral social media messages, brands can be destroyed, if they fail to manage the output of user content. 
Table 5. Excluded variables from the Social Media Model

\begin{tabular}{ccccc}
\hline \multicolumn{5}{c}{ Excluded Variables $^{\mathbf{a}}$} \\
\hline & Model & Beta In & t & Sig. \\
\hline 3 & SM platform & $-.001^{\mathrm{d}}$ & -.024 & .981 \\
\hline
\end{tabular}

a. Dependent Variable: Purchase Intention

d. Predictors in the Model: (Constant), SM word of mouth, Firm generated SM communication, User created SM communication

\section{The Effect of User Social Media Word of Mouth on Consumer Purchase Intention}

Using SPSS regression output Table 3 and 4 , the study confirmed that social media word of mouth significantly drives consumer purchase intention $(\mathrm{B}=0.51, \mathrm{~T}=7.27, \mathrm{P}=0.00)$. The association between social media word of mouth and purchase intention had a moderate positive correlation of 0.45 . We therefore reject the null hypothesis and conclude that there is statistically significant evidence that social media word of mouth has a positive impact on consumers' purchase intention $\left(\mathrm{H}_{3}\right)$.

The decision and the results' interpretation are that viral communication is so powerful towards driving consumers to buy. In fact, of all social media determinants analysed in this study, social media word of mouth had the highest positive strength and impact on purchase intention. This means that consumers basically consider viral communications as authentic and informative to trigger their needs, and thus commence the decision process to start.

Even previous empirical findings also agree with the sentiments found in this study. A cross section of studies which analysed the role of word of mouth, showed that word of mouth is a brand builder or destroyer. If companies are on the positive side of word of mouth, brands are built and purchases increase, with the opposing view being equally true (Chivinski and Dąbrowski, 2013; Hoyer and MacInnis, 2016; Nikita, 2019). In that regard, Kulimula (2020) encourages companies to monitor what their consumers talk about.

\section{The Effect of Social Media Platforms on Consumer} Purchase Intention

The study found out that social media platforms that are used universally across all three mobile telephony companies in Zimbabwe were Facebook, Twitter, LinkedIn, YouTube and Instagram. The study further reveals that consumers access all these five platforms. However, the platforms which are mainly accessed by consumers are; Facebook, Twitter, Instagram, LinkedIn and YouTube, in that order.

However, the study was keen to understand if social media platforms influence consumer purchase behaviour. Using stepwise regression, the variable social media platform was excluded from Model 3 as shown in Table 5.

The statistical correlation between social media platform and purchase intention was found to be 0.075 with a p-value of 0.173 (Table 4) Though the association is very weak and positive, the $p$-value shows that it is insignificant. Table 5 also shows a very weak impact of social media platforms, which was also statistically insignificant $(\mathrm{P}=0.981 ; \mathrm{P}>0.05)$. We therefore accept the null hypothesis and conclude that there is no statistically significant evidence that social media platform has a positive impact on consumers' purchase intention $\left(\mathrm{H}_{4}\right)$.
Therefore, the study concludes that social media platforms have no effect on consumer's decision making. It therefore follows that Facebook does not promote purchase intention more or less than Twitter and Twitter does not promote purchase intention more or less than Instagram, and so on. The specific platform which consumers use does not matter, but what matters is the interaction.

The study found diverging results from previous empirical results. Ricardialiono (2020) found out that not all social media platforms have the same level of impact towards influencing purchase intention. A study by Gizlan and Mertucalis (2020) concluded that various types of social networks are used for different purposes by consumers leading to varied consumer intention effects for each platform. However, this study found out that consumers are not affected by the type of social media used.

\section{CONLUSIONS AND RECOMMENDATIONS}

The overall conclusion of the study is that social media drives consumers' intention to buy. However, there is need to enhance the social media campaign so as to stimulate consumers' interest using the correct social media variables. The study concludes that the most engaging social media variable is social media word of mouth. Viral communication on social networks circulates faster and are more believable than information generated by the company. In actual fact, the study concludes that company generated content negatively affect consumer intention. It is therefore recommended to companies in the mobile telephony industry to minimise their generated posts and promote user created posts and sponsored word of mouth marketing. The study also concludes that social media platforms in themselves do not drive intended purchase behaviour. Therefore, companies may run social media campaigns on any social platform.

The major weakness of the study was that the model used was never empirically tested before. Upon a successful test in this study, we recommend future researchers to further test the model in different environments so as to enhance its robustness. Future researchers may also consider adding the influence of the mediating effect of age and gender on the social media marketing and purchase behaviour.

\section{REFERENCES}

Ajzen, I. (1975). The theory of planned behavior. Organizational Behavior and Human Decision Processes, 50(2), 179-211. https://doi.org/10.1016/07495978(91)90020-T 
Ajzen, I. and Fishbein. M. (1991). The theory of planned behaviour; Organisational Behaviour and Human Decision Processes. Journal of Theoretical and Applied Information Technology, 55(1), 33-54.

Alnsour, M., Ghannam, M. and Al-natour, R. (2018). Social media effect on purchase intention: Jordanian airline industry. Journal of Internet Banking and Commerce, 23(2), 3-17.

Al-qasa, K., Isa, F. and Othman, S. (2013). Factors Affecting Intentions to Use Banking Services in Yemen. Journal of Internet Banking and Commerce, 18(2), 122-131.

Bharucha, J. (2018). Social Media and Young Consumers Behavior. International Journal of Supply Chain Management, 7(6), 72-81.

Bruno, S. and Dariusz, D. (2013). The effect of social-media communication on consumer perceptions of brands. Journal of Economics and Management, 12(2), 1-21.

Campbell, C., Ludahn, N., and Zholnal, C. (2011). The differential effect of social media on consumer behavioral intention. Journal of Behavioural Studies, 14(2), 162-178.

Collins, C. (2015). Business Research Methods, Principles and Practices. Lower Manhattan.

Diebes, H. and Iriqat, R. (2019). Social media as a strategic marketing communication tool in Palestinian mobile telecom companies - business to customers relationship perspective. International Review of Management and Marketing, 9(3), 31-40. https://doi.org/10.32479/irmm.7714

Econet Wireless (2020). Our social media activities. Available at: http://www.econetwireless.co.zw/our-social-mediaactivities (Accessed: 03 March 2020).

Eqwubo, E. (2020). The effect of social media towards driving consumer intention in Ghana. International Journal of Business Administration and Economics, 4(2), 78-89.

Ghannam, M., Al-natour, R. and Alzeidat, Y. (2018). Social media effect on purchase intention: Jordanian airline industry. Journal of Internet Banking and Commerce, 23(2), 3-17.

Gizlan, M. and Mertucalis, G. (2020) Social media marketing and consumer behaviour in contemporary business management. International Journal of Social Studies and Commerce, 2(1), 14-26.

GlobeStat. (2020). Social media statistics. Global Statistics Forum.

Gros, C. (2012). The influence of Social Media on consumers during their purchase decision-making process and the implications for marketers. Dublin Business School Review.

Hoyer, M. and MacInnis, H. (2016). Measuring customer engagement with social media in uncontrolled environments. International Journal of Social Sciences, 6(1), 22-37.

Kohli, S., Suri, K. and Kapoor, K. (2014). The impact of user interactions in social media on brand awareness and purchase intention: the case of MINI on Facebook, Journal of Product \& Brand Management, 22(5), 342-351. https://doi.org/10.1108/JPBM-05-2013-0299
Kosarizadeh, M. and Hamdi, K. (2015). Studying the effect of social media on consumer purchase intention. (Case Study: Leather Products). Journal of Applied Environmental and Biological Sciences, 5(7), 171-181.

Kulimula, M. (2020). The impact of social networks on consumer behaviour. International Journal of Social Business, 3(2), 22-135.

Lilima, M. (2020). The effects of social media marketing on consumer behaviour. International Journal of Human Behavior, 2(5), 1755-1767.

Maoyan, M., Zhujunxuan, Z. and Sangyang, S. (2014). Consumer purchase intention research based on social media marketing. International Journal of Business and Social Science, 5(10), 92-97.

Meslat, N. (2018). Impact of social media on customers' purchase decision. Turku Journal of Applied Sciences.

Ndurura, N. (2020). The significance of social media as a marketing tool. International Journal of Business and Environmental Studies, 7(1), 12-26.

Never, M. (2019). The impact of social media on consumer behavior. International Journal of Sciences and Management, 6(2), 143-152.

Nikita, N. (2017). Social media adoption in selected African countries. International Journal of Business and Behavioural Sciences, 9(1), 57-69.

Oleynikovaa, Z. and Zorkina, O. (2016). Conceptualising social commerce, an exploratory study. Journal of Interactive Marketing, 30(4),198-208.

Parasuraman, A. L. L. Berry, V. A. and Zeithaml, Z. (1996). A conceptual model of service quality and its implications for future research. Journal of Marketing, 49(4), 41-50.

Permatasari, A. and Kuswadi, E. (2018). The impact of social media on consumers' purchase intention: A study of ecommerce sites in Jakarta, Indonesia. Review of Integrative Business and Economics Research, 6(1), 321-335.

Poturak, M. and Softić, S. (2019). Influence of social media content on consumer purchase intention: mediation effect of brand equity. Eurasian Journal of Business and Economics, 23(12), 17-43. https://doi.org/10.17015/ejbe.2019.023.02

Putter, M. (2017). The impact of social media on consumer buying intention. Journal of International Business Research and Marketing, 3(1), 7-13. https://doi.org/10.18775/jibrm. 1849-8558.2015.31.3001

Rad, R., Joyin, R. and Moyada, C. (2011). Modelling social commerce. Journal of Business Management, 11(2), 37-51.

Ramsunder, M. (2011). The impact of social media marketing on purchase decisions in the tyre industry. Metropolitan Business Review.

Ricardialiono, R. (2020). Understanding social commerce: A systematic review and direction for future research. International Journal of Information Management, 3(6), 1075-1088.

Saunders, M., Lewis, P. and Thornhill, A. (2015). Research Methods for Business Students ( $5^{\text {th }}$ ed.), Harlow, England: Pearson Education. 
Schivinski, B. and Dabrowski, D. (2019). The effect of social media communication on consumer perceptions of brands. Journal of Management and Economics, 17(3), 212-222.

Tapfumaneyi, F. (2015). The impact of social media on brand equity in the financial sector in Zimbabwe: A case study of ZB bank. Zambezia Journal of Business Management.

Techzim. (2019). Social media proliferation in Zimbabwe: 2005 to 2019. Techzimmag Publishers.

Venkatesh, V., Morris, M. G., Davis, G. B. and Davis, F. D. (2003). User acceptance of information technology: toward a unified view. MIS Quarterly, 27(3), 425-478. https://doi.org/10.2307/30036540
Yin, Y., Malik, M. E. and Ghafoor, M. M. (2019). Impact of Brand Image, Service Quality and price on customer satisfaction in Pakistan Telecommunication sector. International Journal of Business and Social Science, 3(23).

Yoong, L. and Lian, S. (2019). Customer engagement in social media and purchase intentions in the hotel industry. International Journal of Academic Research in Business and Social Sciences, 9(1), 54-68. https://doi.org/10.6007/ IJARBSS/v9-i1/5363

Zhou, T. and Zimmermann, Z. (2013). Customers' assessment of destination advertisements with incomplete information interactions among inferences, attitudes, and purchase intentions. Journal of Quality Assurance and Hospitality \& Tourism, 15(3), 269-293. https://doi.org/ 10.1080/1528008X.2014.921771 